\begin{tabular}{|} 
Ambiente \& Água - An Interdisciplinary Journal of Applied Science \\
ISSN 1980-993X - doi:10.4136/1980-993X \\
www.ambi-agua.net \\
E-mail: ambi.agua@gmail.com
\end{tabular}

\title{
Drinking water quality in Brazilian urban slums
}

\author{
ARTICLES doi:10.4136/ambi-agua.2532
}

Received: 07 Feb. 2020; Accepted: 01 Apr. 2020

\begin{abstract}
Natasha Berendonk Handam ${ }^{*}$;D ; José Augusto Albuquerque dos Santos ${ }^{2}$ iD; Antonio Henrique Almeida de Moraes Neto ${ }^{3}$; Maria de Fátima Leal Alencar ${ }^{3}$; Caroline Ferraz Ignacio ${ }^{(D}$; Adriana Sotero-Martins 5 (D)
\end{abstract}

${ }^{1}$ Programa de Doutorado em Saúde Pública e Meio Ambiente. Escola Nacional de Saúde Pública Sérgio Arouca. Fundação Oswaldo Cruz (FIOCRUZ), Rua Leopoldo Bulhões, n ${ }^{\circ}$ 1480, CEP: 21031-210,

Rio de Janeiro, RJ, Brazil

${ }^{2}$ Laboratório de Avaliação e Promoção da Saúde Ambiental. Instituto Oswaldo Cruz. Fundação Oswaldo Cruz (FIOCRUZ), Avenida Brasil, n 4365, CEP: 21040-360, Rio de Janeiro, RJ, Brazil.

E-mail: santosjaa@gmail.com

${ }^{3}$ Laboratório de Inovações em Terapias, Ensino e Bioprodutos. Instituto Oswaldo Cruz. Fundação Oswaldo Cruz (FIOCRUZ), Avenida Brasil, n 4365, CEP: 21040-360, Rio de Janeiro, RJ, Brazil.

E-mail: ahmn@ioc.fiocruz.br, fatima_alencar57@yahoo.com.br

${ }^{4}$ Programa de Doutorado em Medicina Tropical. Instituto Oswaldo Cruz. Fundação Oswaldo Cruz (FIOCRUZ), Avenida Brasil, n 4365, CEP: 21040-360, Rio de Janeiro, RJ, Brazil. E-mail: carolinini19@gmail.com

${ }^{5}$ Departamento de Saneamento e Saúde Ambiental. Escola Nacional de Saúde Pública Sérgio Arouca. Fundação

Oswaldo Cruz (FIOCRUZ), Rua Leopoldo Bulhões, n 1480, CEP: 21041-210, Rio de Janeiro, RJ, Brazil.

E-mail: adrianasotero@ensp.fiocruz.br

*Corresponding author. E-mail: natashabhandam@gmail.com

\section{ABSTRACT}

The study analyzed the quality of drinking water used in Brazilian urban slum residences according to the standards established in Brazilian regulations. Bacteriological $(n=231)$ and physicochemical parameters $(n=134)$ were analyzed, as the Standard Methods for the Examination of Water and Wastewater establishes. The results revealed that contaminants in the water consumed, for the most part, exceed the limits of drinking water quality standards, putting the population's health at risk and reinforcing the urgency of the need for public policies.

Keywords: drinking water, physicochemical and coliforms analysis, water quality.

\section{Qualidade da água para consumo humano em favelas urbanas Brasileiras}

\section{RESUMO}

O objetivo do estudo foi analisar a qualidade da água potável utilizada nas residências em favelas urbanas brasileiras, de acordo com as normas estabelecidas nas legislações Brasileiras. Os parâmetros bacteriológicos $(n=231)$ e físico-químicos $(n=134)$ foram analisados, de acordo com Standard Methods for the Examination of Water and Wastewater. Os resultados revelaram que a água consumida, em grande parte, excede os límites dos padrões de qualidade de água potável, o que coloca em risco a saúde da população e reforça a urgência das políticas públicas sociais.

Palavras-chave: água potável, análise bacteriológica e físico-química, qualidade da água. 


\section{INTRODUCTION}

In Brazil, according to the last Demographic Census of 2010 of the Brazilian Institute of Geography and Statistics (IBGE), 11,425,644 people, corresponding to 6\% of the Brazilian population, live in one of the 6,329 identified slums. The city of Rio de Janeiro is one of the cities that has more people living in these areas, with 1,393,314 residents in 763 slums, constituting $22 \%$ of the city's total population (IBGE, 2010). In general, in urban slums, urban infrastructure (water supply, sewage, solid waste collection and drainage) is more precarious, leaving the population more susceptible to social injustices. This demonstrates the inability of public officials to meet and supervise the provision of social demands for adequate housing and sanitation, as well as the proper implementation of urban public services (Lopes et al., 2011). The diseases that occur in the slums are largely related to the absence of adequate sanitation, agglomerated populations without planning, and consequently precarious conditions of personal hygiene and housing (Ferreira, 2009). The consequences faced by the population associated with the lack of sanitation and the expenses of the National Health System are high, due to hospitalizations and the excessive use of medications. However, most waterborne diseases could be avoided with an adequate sewage system and adequate water supply in residences (Ignacio et al., 2017; Handam, 2016).

It is estimated that drinking water contamination causes 485,000 deaths per year due to diarrheal diseases (WHO, 2017). With the conditions of contaminated water and low immunity, people who drink water can acquire diseases, such as diarrheal diseases, hepatitis A, rotavirus, giardiasis, amoebiasis (Brasil, 2006). Therefore, to ensure the human right to water and avoid health risks, drinking water, preparation and production of food and personal hygiene must meet the water quality standards set out in the legislation. The population's water supply and drinking water must be guaranteed.

However, water supply in Brazil's slums is a major problem of social inequality, as water supply is not guaranteed. There are pressures that affect the water supply in this type of territory. As slum dwellers do not have access to water supplies, they take over the position of the government and provide clandestine connections, where they draw water from the formal connections that run through the slums of the government's sanitation company. These illegal connections cannot ensure the quality and sufficient quantity of water for the population, but these forms of supply are necessary for the survival of the people, who cannot afford the costs of water supply by governmental water service providers. (Rodrigues, 2016).

In addition, when a water crisis occurs, they are the first places where maneuvers take place, and thus there is a lack of water supply, since they are regions that have the largest number of households benefited by social tariffs from government programs, and do not generate a return on profit expected for sanitation service providers. In these territories, water maneuvers take place by a resident hired by the water service providers, who is in charge of these maneuvers. These slum dwellers are responsible for managing the water systems (Rodrigues, 2016). In addition, violence and parallel power over the dominance of drug trafficking in these locations can define who receives or does not receive water. Most slum residents currently live with drug-related violence and conflicts with shootings between drug dealers and the police. This situation affects the lives of residents who need to leave their homes, for example, to study and work, making people victims. Reducing these conflicts would allow improved access to public health promotion services and other initiatives for slum dwellers, such as improving water and sewage systems (Handam, 2016).

In the Brazilian slums, treated water that is distributed by the sanitation companies to the homes can be contaminated along the way due to the clandestine connections used by residents to obtain water. Generally, due to the economic inequalities of the residents, the material used for clandestine water connections in slums are made with materials with low durability and 
without safety mechanisms, and also exposed to irregular sewage pipes through which the sewage is dropped due to lack of expert guidance (Barcellos et al., 1998). Due to tubes damaged by rupture, in periods of intermittency or lack of water supply, the pressure favors the entry of biological and chemical contaminants present in the soil into the tubes, polluting the water. (Carmo, 2009). Another form of contamination that slum residents are subject to is found in the processes of storing drinking water, including containers such as water reservoirs. When this is not done properly, pathogens and/or vectors may proliferate, such as arbovirus-transmitting mosquitoes, intestinal parasite cysts and bacteria that cause gastroenteritis (Sotero-Martins, 2014).

In Brazil, the water quality standards are established in Consolidation Ordinance No. 5 of 2017, which revoked Ministry of Health (MH) Ordinance No. 2914 of 2011. According to the legislation, drinking water must not contain total coliforms nor Escherichia coli (E. coli). This regulation also establishes the Maximum Permitted Values (MPV) for the physicochemical parameters of water (Brasil, 2017). The drinking water from commercial gallons, also called bottled water, must be in accordance with the National Health Surveillance Agency (ANVISA), of the Brazilian Ministry of Health, Collegiate Board Resolution No. 275/2005 (Anvisa, 2005).

In this context, the objective of the study was to analyze the drinking water quality used in residences in urban slums of Rio de Janeiro, RJ, Brazil, according to the standards established in Brazilian regulations, and to use socio-environmental questions to produce indicators regarding exposure to health conditions in these slums.

\section{MATERIALS AND METHODS}

The study was developed in the thirteen slums of Manguinhos, with 38,461 people living in 12,528 residences, located in Rio de Janeiro, RJ, Brazil (-22 $52^{\prime} 47.04 "$ S; $\left.-43^{\circ} 14^{\prime} 57.18^{\prime \prime} \mathrm{W}\right)$ (Teias-Escola Manguinhos, 2013). The territory has one of the lowest Human Development Indexes (HDI) (IBGE, 2010). The overall study area is characterized by serious social and environmental problems, such as: clandestine electrical and plumbing connections to official networks; poorly ventilated, shaded and overpopulated houses; contamination of water reservoirs by poorly channeled sewers. Sewage is discarded in septic tanks built by the residents themselves, either on the streets and sidewalks or directly on nearby rivers. These slums, as usually happens with other Brazilian slums, suffer from high levels of violence associated with drug trafficking (Ignacio et al., 2017; Ignacio, 2017; Handam et al., 2018).

In order to evaluate the water quality, the number of residences for water collection was determined considering a simple random sampling, which represented $1 \%$ of each community of Manguinhos, totaling 123 residences for water collection (Handam, 2016). Water samples were collected from filters, bottled waters and taps in the kitchen of the residences. In total, 134 samples of water were collected from taps, 87 from filters and 10 samples from bottled waters, totaling 231 analyzed samples of classified drinking water.

For the analysis of drinking-water quality, bacteriological (total coliforms and E. coli) and physicochemical parameters (turbidity, $\mathrm{pH}$, free residual chlorine, total alkalinity, total hardness, nitrogen ammonia, nitrogen nitrite, chloride, conductivity, sulfate and total dissolved solids) were used. Physicochemical analysis was performed only on tap water samples from residences, because these were the main source of drinking water used in all of the dwellings. The methods for bacteriological and physicochemical analysis were based on Standard Methods for the Examination of the Water and Wastewater (APHA et al., 2012), and for bacteriological analyses the samples were analyzed diluted and without dilution (Handam, 2016; SoteroMartins et al., 2017). The filter membrane method ${ }^{19}$ was then used with chromogenic indicator culture medium, Chromocult® Coliform Agar (Cat. No. 1,10426,0100 / 500 Merck) (Handam et al., 2018; Sotero-Martins et al., 2017).

The results of the water analysis of taps and filters were compared to the standard of 
Consolidation Ordinance No. 5 of 2017, that establishes quality standards for drinking water (Brasil, 2017). For bottled water, the results were compared to the Resolution of Collegiate Board (RDC) No. 275/05 of ANVISA (2005).

In order to achieve improvements in the quality of water consumed by residents, an environmental health education guide on caring for water for human consumption was delivered to residents. This guide aims to work with the population on the importance of water quality for human consumption through health education actions. The Guide to environmental education in health was developed through this work in group meetings, with contributions from researchers, students and persons living in the slums, with a simple and illustrative language to facilitate understanding. All the information and recommendations contained in the Guide were used to instruct residents on how to proceed to improve the quality of drinking water, highlighting the importance of the disinfection of water reservoir and water filters (Sotero-Martins et al., 2014).

To assess the quality of the water consumed, the number of residences for water collection was determined considering a simple random sampling, which represented $1 \%$ of each community of Manguinhos, totaling 123 residences for water collection (Handam, 2016). Water samples were collected from filters, bottled waters and taps in the kitchen of residences. In total, 134 samples of water were collected from taps, 87 from filters and 10 samples from bottled water, totaling 231 analyzed samples classified for drinking water.

Through this study, a guide was produced to investigate water quality conditions in slums to assist in conducting similar studies in other parts of the world.

The study was approved and registered by the Research Ethics Committee with Human Beings of the Oswaldo Cruz Foundation / RJ / SISNEP under No. 548/2010.

\section{RESULTS AND DISCUSSION}

Regarding the laboratory results of the physical-chemical analyses of the water samples $(\mathrm{n}=134), 114$ samples $(85 \%)$ presented acidic $\mathrm{pH}$, exceeding the limits of the drinking water quality standards determined by the Brazilian Legislation of the Consolidation Ordinance 5/2017. This Ordinance establishes that the $\mathrm{pH}$ of the water must be between 6.0 and 9.5. In addition, 1 sample was also inadequate due to the chloride parameter in the Amorim slum $(285.95 \mathrm{mg} / \mathrm{l})$, being 1.14 times the maximum allowed value, according to the legal standards.

The acidity of the water is mainly due to the presence of free carbon dioxide in the water, which can result from the decomposition of organic matter from sewage contamination and industrial dumps (Coêlho, 2017). For human health, water with acidic pH can cause irritation to the skin or eyes of individuals who come in contact (Morais et al., 2016). In addition, if consumed for a long period, ten to twenty years, it can cause gastric problems such as gastritis, ulcers and stomach cancer (Funasa, 2014). The high concentration of chloride causes an unpleasant taste in the water and can cause laxative effects in individuals. Generally, they originate from the dissolution of minerals or from the intrusion of seawater and can still have their origin from domestic or industrial sewage (Funasa, 2014). Therefore, this indicates that the water that reaches the taps of the houses is in unhealthy conditions and a risk to health.

Coêlho et al. (2017) observed in São Luís City, State of Maranhão, that the pH values were below those recommended by Brazilian Law No. 5/2017, with results similar to those observed in this study. Chlorides may be present in raw waters and in treated waters, depending on the treatment performed.

The results of total hardness, free residual chlorine, total dissolved solids, total alkalinity, ammonia, nitrite, sulfate and turbidity were in accordance with the maximum allowed values described by the Ordinance of Consolidation $\mathrm{n}^{\circ} 5$ of 2017 . The slums that presented the highest mean levels of the parameters were: total hardness, in the Amorim slum (41.42 \pm 17.18$) ; \mathrm{pH}$, in 
the Vila União slum (5.85 \pm 0.25$)$; conductivity, in the Nelson Mandela slum (315.75 \pm 145.16$)$; TDS, in the Nelson Mandela slum (158.32 \pm 72.69$)$; free residual, in the CAH slum (2.05 \pm 1.77$)$; chloride, in the Amorim slum $(65.68 \pm 99.52)$; total alkalinity $(40.99 \pm 1857)$ and $\mathrm{N}$-nitrite $(0.037 \pm 0.018)$, in the Samora Machel slum; N-ammonia $(0.055 \pm 0.024)$ and sulfate (21.32 \pm 4.92$)$, in the CHP2 slum; and turbidity, in the V. turismo slum (1.4 \pm 1.06$)$.

The results of the bacteriological analyses of the water samples, considering both bioindicators, total coliforms and E. coli, showed that $27 \%(26 / 97)$ of the water samples collected from the filters and the bottled water meet the quality standard, and that $73 \%(71 / 97)$ exceed the limits of the quality standards of the legislations: Consolidation Ordinance No. 5/2017 and Collegiate Board Resolution (RDC) No. 275/05 of ANVISA (Figure 1). For water samples collected from taps, 31\% (42/134) meet the quality criteria and 69\% (92/134) exceed the limits of the drinking water quality standards of the Consolidation Ordinance $n^{\circ} 5 / 2017$ (Figure 2).

In a study conducted in favelas, it was observed that $58.8 \%$ of tap water samples, which were not in accordance with the Brazilian Regulation, obtained positive results for total coliforms and positive for E. coli (Pereira et al., 2015). According to De Souza et al. (2015), slums in the city of Campos dos Goytacazes, Rio de Janeiro, presented a sample of tap water at home outside the established bacteriological standards for water quality, with a level 35 times higher of UFC/ml of total coliforms above the permitted by law and 10 times the UFC/ml level of thermotolerant coliforms above that allowed by regulation. The presence of coliforms in the water indicates the possible presence of other pathogenic microorganisms and their absence indicates that other organisms are not present in the water (Sotero-Martins et al., 2017).

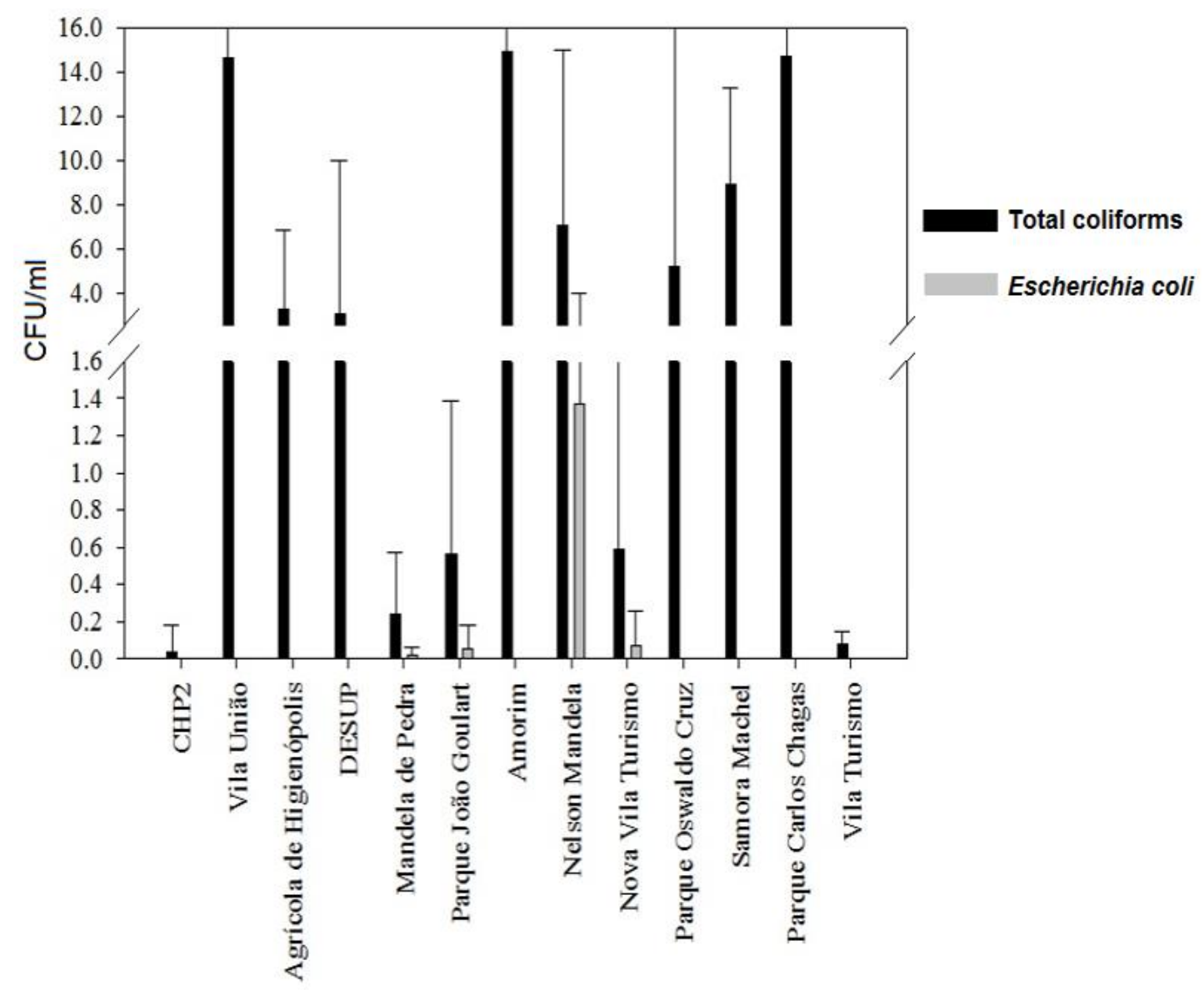

Figure 1. Mean levels of contamination by total coliforms and Escherichia coli in the water samples of filters and bottled water in the Manguinhos slums, RJ, Brazil $(\mathrm{n}=97)$. Break interval: $1.6-2.5$. 


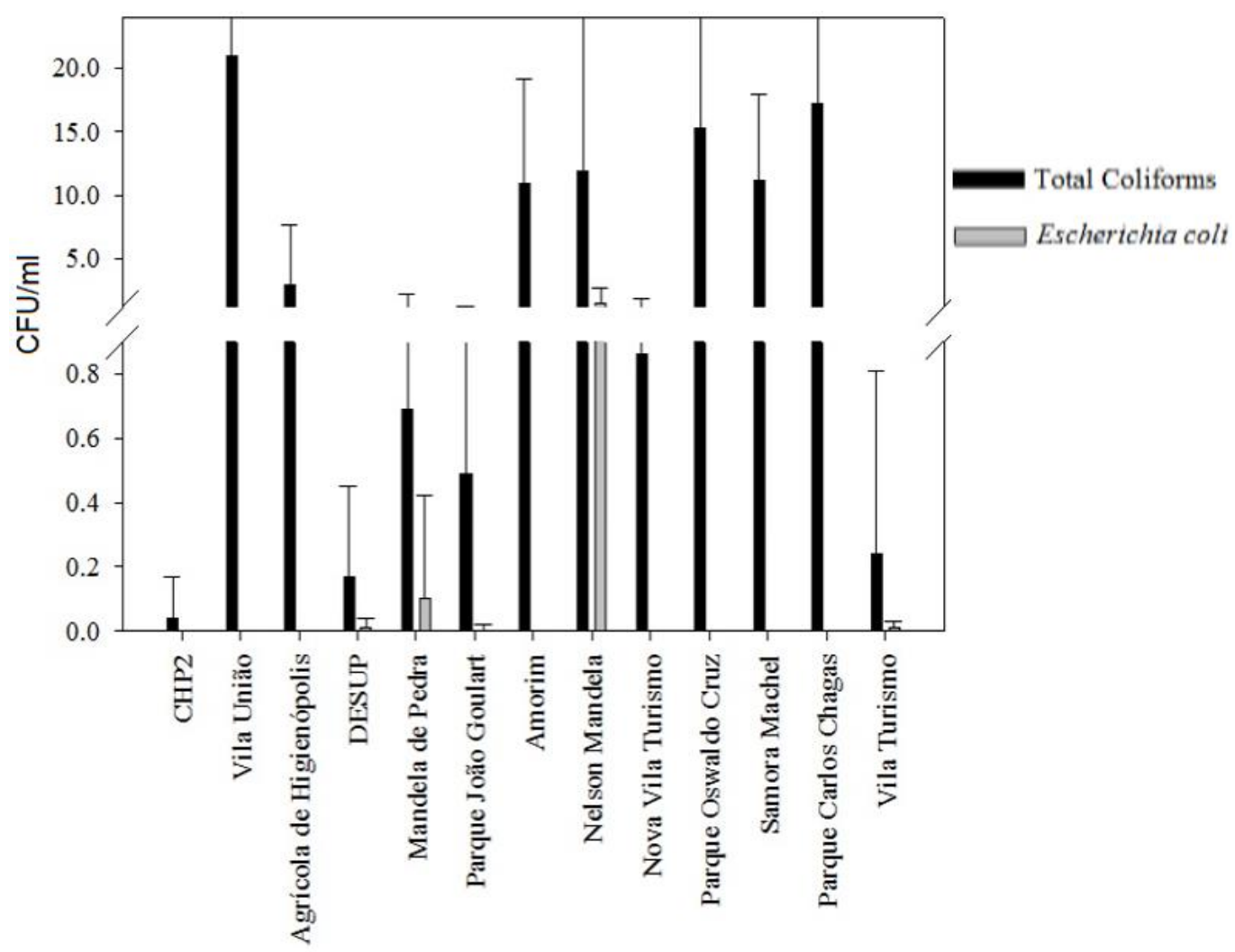

Figure 2. Mean levels of contamination by total coliforms and Escherichia coli in samples of tap water in the Manguinhos slums, RJ, Brazil $(n=134)$. Break interval: 0.9 -1.2 .

Porcy et al. (2020) evaluated water samples collected in residences located on the outskirts of the city of Macapá. This study showed that $34.8 \%$ of households had positive results for total coliforms and $26.1 \%$ for coliform thermotolerant, which could cause problems for human health.

Corroborating the study according to Reis et al. (2014), levels above the total coliform levels were found in bottled water samples. According to RDC ANVISA $n^{\circ} 275 / 200519$, the quality of bottled water is inappropriate when there is an absence of $E$. coli and when it has values equal to or greater than $<1.1 \mathrm{MPN}$ for total coliforms.

The simultaneous evaluation of bioindicators - bacteriological and physical-chemical parameters - of samples collected from taps, showed that only $10 \%(13 / 134)$ meet the quality standards. The situation worsens when we consider both analysis parameters: $90 \%(122 / 134)$ of the waters consumed in the territory exceed the limits of the drinking water quality standards, according to the Ordinance of Consolidation $\mathrm{n}^{\circ} 5$ of 2017.

The results of water samples that did not meet the quality standards were similar in samples collected from taps, filters and bottled water, demonstrating that the water supplied to the residences in this territory is unreliable, and requires care to eliminate contaminants for human consumption, mainly for drinking and washing food in order to avoid possible health problems, such as diarrheal diseases.

The reasons for water contamination may be due to domestic conditions, such as lack of cleanliness of the water tank, unchanged filter refills, and inadequate water conduit installation (i.e., next to sewerage). This contamination may also be due to the water distributed by the sanitation company and contamination during the distribution, which was provided by residents through clandestine connections without guarantees of quality to the home. Since these connections are generally constructed with poor quality materials and can also be exposed to 
irregular sewage pipes, when there are intermittent periods in the supply of water or lack of water and a rupture in the pipes the pressure can favor the entry of soil contaminants into the pipes, polluting the water.

In parallel with the lack of care provided by residents with drinking water in their homes in relation to storage, it was identified in 2015 that the water distributed by the Rio de Janeiro sanitation company (CEDAE) was contaminated by coliforms, reproducing thermololerants in the piped water of the Guandu system (TrataBrasil, 2015). Recently, the water distributed by the company has a high presence of potentially toxic algae, which give bad conditions of turbidity, odor and taste of cold water in the metropolitan region of Rio de Janeiro (Alencar, 2020).

Other Brazilian slums also do not have regular water supply even located in the urban area of the city, as in the case of the Tamarindo slum. This slum has clandestine pipes to obtain water (De Souza et al., 2015).

In other studies (Pereira et al., 2015; Araújo et al., 2011) from urban slums, the population also consumed water directly from the tap and most water samples exceed the limits of the drinking water quality standards due to total coliforms and E. coli. Contamination of water tanks can occur through animal feces present in water storage, in addition to the failure of some residents to periodically clean the water tank. The reason for the lack of cleaning can be due to the difficulty of accessing the place where the water tank is installed and the lack of information about the periodicity and the cleaning procedure. The Guidance recommends that this cleaning be performed at least once a year (Handam, 2016; Sotero-Martins et al., 2014), treating cleaning as a yearly ritual. Contamination of the water collected from filters may be due to lack of maintenance and care. Residents may not be using the filter properly, not performing according to the manufacturer's recommendation. Before blaming residents, it should be noted that the high cost of filters is an important barrier, especially in these vulnerable socioeconomic communities. In addition, there were also reports of residents who had to change the refill of the filter before six months, aiming to improve the quality, because the color of the water was already dark. When filter refill is not replaced properly or when the water being filtered has extremely poor quality, the filtering function can lose its efficiency allowing the passage and microorganisms. The water filtration in the residences brings benefits in the prevention of diarrhea in all age groups, being important the expansion of health education actions that aim the use of water filters in homes, in which public treatment is absent or fails. In addition, the use of household water filters is strongly related to the reduction of the general prevalence of helminths and protozoa (Belo et al., 2012).

The contamination of the bottled water may occur at the source, in the container, or during transport and storage (Inmetro, 2009). When the packaging is not adequately sealed and the environmental temperature is high, these factors allow the passage of oxygen, favoring the entry and proliferation of bacteria in the water as well as the release of nutrients from the plastic (Rosenberg, 2003).

The process of storing drinking water due to intermittent water in slums is a risky process for health because there are used containers, such as pools and buckets, which are not appropriate, and can be sites of proliferation of disease vectors, such as the arboviruses. Therefore, guidelines should be made on the most correct way of storing and guaranteeing disinfection of water, for example by carrying out the addition of chlorine in the appropriate amount per ml. Thus, one of the actions of the study to improve water quality to the population of the slums was to use the Environmental Health Education Guide entitled "Drinking Water: Care and Tips" (Sotero-Martins et al., 2014). The environmental health education material developed was explained in the houses participating in the study. They were instructed on how to treat water that may be contaminated by biological agents (bacteria, viruses, protozoa, helminths); how to be careful with filters; and how to store water with quality. It was also given 
a sheet to be fixed in the refrigerator or behind the kitchen door. So, the resident could record the change and cleaning dates of the filter, and the dates of cleaning the water tank. In view of the results of water quality, residents of the slums of Manguinhos were advised not to consume water directly from the tap, being indicated the use of filters, boiling or chlorination of the water, as well as the cleaning of the water tank and the exchange filter refill periodically. In addition, this guiding material can also be used in residences in other regions of Brazil and of the world with characteristics similar to those of the present study, helping to improve the quality of water for human consumption and consequently preventing disease and improving the population's health.

\section{CONCLUSIONS}

This study revealed that the health of the population of slums is at risk due to the quality of drinking water consumed by the population, in general exceeding the limits of the drinkingwater quality standards determined by Brazilian Legislation. Health education actions, such as the delivery of water-quality reports with basic recommendations on how to improve water quality and the environment, support residents to adopt measures to prevent water-borne diseases, such as good hygiene practices, careful cleaning of the reservoirs and water filters at the recommended frequencies. The analyses point to the greatest social and environmental vulnerability and the priorities of the regions for governmental actions to reduce health inequities, such as education, access to health services and access to sewage and water treatment.

\section{ACKNOWLEDGEMENTS}

Funding for this study was provided by: the Fundação Carlos Chagas Filho de Amparo à Pesquisa do Estado do Rio de Janeiro (FAPERJ) [Grant E-26/010.001915/2014 Edital ExtPesq 16/2014]; Financiadora de Estudos e Projetos (FINEP) [Accord FINEP/FIOCRUZ 01.11.0025.00, Rede Morar.Ts]; Vice-Presidência de Ambiente, Atenção e Promoção da Saúde (VPAAPS)/Vice-Presidência de Pesquisas e Laboratórios de Referência (VPPLR)/ TEIAS Escola Manguinhos; the Instituto Oswaldo Cruz (IOC/FIOCRUZ); and Departamento de Saneamento e Saúde Ambiental (DSSA) da Escola Nacional de Saúde Pública Sergio Arouca (ENSP/FIOCRUZ).

\section{REFERENCES}

ALENCAR, E. Fiocruz atesta presença de cianobactérias potencialmente tóxicas no Guandu. Eco, 12 Mar. 2020. Available at: https://www.oeco.org.br/reportagens/fiocruz-atestapresenca-de-cianobacterias-potencialmente-toxicas-no-guandu/. Access: 20 Apr. 2020.

AGÊNCIA NACIONAL DE VIGILÂNCIA SANITÁRIA (Brasil). Resolução-RDC no 275, de 22 de setembro de 2005. Diário Oficial [da] União: seção 1, Brasília, DF, n. 184, p. 377 378,23 set. 2005.

APHA; AWWA; WEF. Standard Methods for the examination of water and wastewater. 22nd ed. Washington, 2012. 1496 p.

ARAÚJO, R. G. F.; ALVES, R. I. S.; TONANI, K. A. A. et al. Qualidade físico-química e microbiológica da água para o consumo humano e a relação com a saúde: estudo em uma comunidade rural no estado de São Paulo. O Mundo da Saúde, v. 35, p. 98-4, 2011.

Rev. Ambient. Água vol. 15 n. 3, e2532 - Taubaté 2020 
BARCELlOS, C.; COUTINHO, K.; PINA, M. F.; MAGALHÃES, M. M. A. F.; PAOLA J. C. M. D.; SANTOS S. M. Inter-relacionamento de dados ambientais e de saúde: análise de risco à saúde aplicada ao abastecimento de água no Rio de Janeiro utilizando Sistemas de Informações Geográficas. Cadernos de Saúde Pública, v. 14, p. 597-05, 1998. https://doi.org/10.1590/S0102-311X1998000300016

BELO, V. S.; OLIVEIRA, R. B. de; FERNANDES, P. C.; NASCIMENTO, B. W. L.; FERNANDES, F. V.; CASTRO, C. L. F.; SANTOS, W. B. dos; SILVA, E. S. da. Fatores associados à ocorrência de parasitoses intestinais em uma população de crianças e adolescentes. Revista Paulista de Pediatria, v. 30, p. 195-01, 2012. https://doi.org/10.1590/S0103-05822012000200007

BRASIL. Ministério da Saúde. Portaria n. 05, de 28 de setembro de 2017. Consolidação das normas sobre as ações e os serviços de saúde do Sistema Único de Saúde. Diário Oficial [da] União: seção 1, Brasília, DF, n. 190, supl. p. 516-531, 03 de out. de 2017.

BRASIL. Ministério da Saúde. Secretaria de Vigilância em Saúde. Vigilância e controle da qualidade da água para consumo humano. Brasília, DF, 2006.

CARMO, F. J. J. Vazamentos na rede de distribuição de água: impactos no faturamento e no consumo de energia elétrica do $3^{\circ}$ setor de abastecimento de água da região metropolitana de Belém. 2009. Dissertação (Mestrado em Engenharia Civil) Universidade Federal do Pará, Belém, 2009.

COELhO, S. C.; DUARTE, A. N.; AMARAL, L. S.; SANTOS, P. M.; SALLES, M. J.; SANTOS, J. A. A.; SOTERO-MARTINS, A. Monitoramento da água de poços como estratégia de avaliação sanitária em comunidade rural na Cidade de São Luís, MA, Brasil. Revista Ambiente \& Água, v. 12, n. 1, 2017. https://doi.org/10.4136/ambi-agua.1962

COÊLHO, S. C. Condições Sanitárias do Solo e da Água de Poços Tubulares da Comunidade Rural "Cinturão Verde" de São Luís - MA: Parâmetros Físicos e Químicos, Colimétricos e Parasitológicos. 2017. 127 p. Dissertação (Mestrado em Saúde Pública e Meio Ambiente) - Escola Nacional de Saúde Pública Sergio Arouca, Fundação Oswaldo Cruz, Rio de Janeiro, 2017.

DE SOUZA, F. P.; PERTEL, M.; TEIXEIRA, T.; FERREIRA, A. V.; MENEZES, L. E. DE C. F.; PEREIRA, P. S. F. Qualidade da Água de Abastecimento da Comunidade Tamarindo em Campos dos Goytacazes/RJ. Perspectivas Online: Exatas \& Engenharias, v. 5, n. 11, 2015. https://doi.org/10.25242/885X5112015602

FERREIRA, A. Favelas no Rio de Janeiro: nascimento, expansão, remoção e, agora, exclusão através de muros. Biblio 3W, Revista Bibliográfica de Geografía y Ciencias Sociales, v. 14, 2009.

FUNASA (Brasil). Manual de controle da qualidade da água para técnicos que trabalham em ETAS. Brasília. 2014.

HANDAM, N. B.; ALBUQUERQUE DOS SANTOS, J. A.; MORAIS NETO, A. H. A.; DUARTE, A. N.; ALVES, E. B. S.; SALLES, M. J.; SOTERO-MARTINS, A. Sanitary quality of the rivers in the Communities of Manguinhos' Territory, Rio de Janeiro, RJ. Revista Ambiente \& Água, v. 13, 2018. https://dx.doi.org/10.4136/ambi-agua.2125

HANDAM, N. B. Condições sanitárias da água residencial, do solo peridomiciliar e dos rios das comunidades do território de Manguinhos, RJ. 2016. 141 f. Dissertação (Mestrado em Saúde Pública e Meio Ambiente) - Escola Nacional de Saúde Pública Sergio Arouca, Fundação Oswaldo Cruz, Rio de Janeiro, 2016. 
IBGE. Resultados do Censo 2010. 2010. Available at: http://www.ibge.gov.br/home/estatistica/populacao/censo2010/resultados_dou/RJ2010. pdf. 2010. Access: 15 Oct. 2018

IGNACIO, C. F.; SILVA, M. E. C.; HANDAM, N. B.; ALENCAR, M. F. L.; SOTEROMARTINS, A.; BARATA, M. M. L.; MORAES-NETO, A. H. A. Socioenvironmental conditions and intestinal parasitic infections in Brazilian urban slums: a cross-sectional study. Revista do Instituto de Medicina Tropical de São Paulo, v. 59, n. 56, 2017. https://dx.doi.org/10.1590/S1678-9946201759056

IGNACIO, C. F. Determinação Social das Infecções por Parasitas Intestinais na Estratégia de Saúde da Família: uma Contribuição para a Humanização do Serviço. 2017. 341 f. Tese (Doutorado em Medicina Tropical) - Fundação Oswaldo Cruz, Instituto Oswaldo Cruz, Rio de Janeiro, 2017.

INMETRO (Brasil). Normalização e qualidade industrial: água mineral em garrafões de 201. Available at: www.inmetro.gov.br/consumidor/produtos/garrafoes.asp. 2009. Access: 03 Dec. 2017.

LOPES, P. G.; AMORIM, V.; CAVALLIERI, F. Favelas cariocas: comparação das áreas ocupadas 2004-2011. Rio. Rio de Janeiro: Instituto Pereira Passos; Secretaria de Urbanismo, Prefeitura da Cidade do Rio de Janeiro, 2011.

MORAIS, W. A.; SALEH, B. B.; ALVES, W. S.; AQUINO, D. S. Qualidade sanitária da água distribuída para abastecimento público em Rio Verde, Goiás, Brasil. Cadernos de Saúde Coletiva, v. 24, p. 361-7, 2016. https://doi.org/10.1590/1414-462x201600030143

PEREIRA, A. A.; TEIXEIRA, D. C. S.; SILVA, L. R. B.; LIMA JR., L. R. B.; HIGINO, E. Investigação da Qualidade da Água para Consumo Humano na Comunidade do Muquiço na Zona Norte do Rio de Janeiro. Revista Presença, v. 1, 2015.

PORCY, C. et al. Avaliação microbiológica da água de consumo de casas localizadas em área alagada em um município do esta do Amapá. Revista Eletrônica Acervo Saúde, v. 12, n. 4, p. e2938, 2020. https://doi.org/10.25248/reas.e2938.2020

REIS, L. R.; BEVILACQUA, P. D.; CARMO, R. F. Água envasada: qualidade microbiológica e percepção dos consumidores no município de Viçosa (MG). Cadernos Saúde Coletiva, v. 22, n. 3, p. 224-232, 2014. https://doi.org/10.1590/1414-462X201400030002

RODRIGUES, R. I. (Org.). Vida social e política nas favelas: pesquisas de campo no Complexo do Alemão. Rio de Janeiro: Ipea, 2016.

ROSENBERG, F. A. The microbiology of bottled water. Clinical Microbiology Newsletter, v. 25, p. 41-4, 2003. https://doi.org/10.1016/S0196-4399(03)80019-3

SOTERO-MARTINS, A.; HANDAM, N. B.; MOURA, P. G.; AMARAL, L. S.; CALDAS, L. V. L.; CARVAJAL, E. Methods for Sanitary Inspection of Microbiological and Parasitary Quality of Water and Sand of Recreation Areas. American Journal of Engineering Research (AJER), v. 6, p. 56-2, 2017.

SOtero-MARtins, A.; SANTOS, J. A. A.; MORAES NETO, A. H. A. et al. Água Potável: cuidados e dicas. Brasília: ANA, 2014. (Caderno de Saúde Pública e Ambiente, n. 1)

TEIAS-ESCOLA MANGUINHOS. Território Escola Manguinhos: caracterização do território. 2013. Available at: http://andromeda.ensp.fiocruz.br/teias/saudedafamilia/ Access: 01 Oct. 2018. 
TRATABRASIL. Amostras de água da Cedae com coliformes fecais aumentam 50\% 2015. Available at: http://www.tratabrasil.org.br/amostras-de-agua-da-cedae-com-coliformesfecais-aumentam-50. Access: 25 Jan. 2019.

WHO. Guidelines for drinking-water quality: fourth edition incorporating the first addendum. Geneva, 2017. 